\title{
Rhétorique et drame, ou la dialectique du chaud et du froid
}

\section{Henri Suhamy}

\section{(2) OpenEdition \\ Journals}

\section{Édition électronique}

URL : http://journals.openedition.org/shakespeare/1241

DOI : 10.4000/shakespeare.1241

ISSN : 2271-6424

\section{Éditeur}

Société Française Shakespeare

\section{Édition imprimée}

Date de publication : 1 novembre 1992

Pagination : 157-168

Référence électronique

Henri Suhamy, "Rhétorique et drame, ou la dialectique du chaud et du froid ", Actes des congrès de la Société française Shakespeare [En ligne], 10 | 1992, mis en ligne le 01 janvier 2007, consulté le 06 mai 2019. URL : http://journals.openedition.org/shakespeare/1241 ; DOI : 10.4000/shakespeare.1241

Ce document a été généré automatiquement le 6 mai 2019.

(C) SFS 
Rhétorique et drame, ou la dialectique du chaud et $\mathrm{du}$ froid

Henri Suhamy 